\title{
Measuring the Relationship Between Service Quality and Customer Satisfaction in the Hotel Industry
}

\author{
Mushref Mohammed Qasem Saeed* Zhang Xizheng ${ }^{* *}$ Rasheed Abdulwase $^{* * * *}$ Mohammed A.AL-Methali ${ }^{\text {****** }}$ \\ * Department of Business Administration, Hunan University, China. Faculty of Administrative sciences, Taiz University, Yemen \\ *** Department of E-commerce and Logistics Management, Hunan University, China \\ **** School of Management, Jiangsu University, Jiangsu Province, China and Faculty of Administrative sciences, Taiz University, Yemen \\ ***** School of Management, Lanzhou University, Gansu Province, China. \\ DOI: 10.29322/IJSRP.11.08.2021.p11644 \\ http://dx.doi.org/10.29322/IJSRP.11.08.2021.p11644
}

\begin{abstract}
- with the development of hotel sector, service quality and customer satisfaction have become the core tools for gaining a competitive advantage, since they are the prerequisites for customer loyalty and higher profitability. Therefore, this study is based on SERVQUAL scale to measure the relationship between service quality and customer satisfaction from the perception of hotel guests in Changsha city, Yuelu District. By using a convenience sampling method, the questionnaire was distributed to 200 respondents in 6 hotels. However, data was collected from 167 completed questionnaires. The data were analyzed by Statistical Package for Social Sciences (SPSS) version 25 and Smart PLS 3. Reliability and validities of latent variables were confirmed. In this study, structural equation modeling (SEM) was used to investigate the relationship between five exogenous variables namely; tangibility, reliability, responsiveness, assurance, and empathy, and an endogenous variable that is customer satisfaction. The findings revealed that all five dimensions of service quality have a positive relationship with customer satisfaction. It also showed that assurance has the most significant factor by hotel customers. This was followed by empathy and then responsiveness while tangibility and reliability as two service quality dimensions have no significant impact on customer satisfaction. This study advances our understanding of the relationship between service quality and customer satisfaction in the hotel industry. Hotel managers can gain benefits by understanding how service quality can achieve a high degree of customer satisfaction, and thus leads to hotel profitability.
\end{abstract}

Index Terms- Customer Satisfaction, Changsha, Hotel Industry, SERVQUAL, Service Quality.

\section{INTRODUCTION}

$\mathrm{T}$ he hotel industry in China has been growing significantly and is expected to continue growing in the future due to its large population, the preference of most Chinese people for domestic tourism, and the increasing number of international tourists. Simultaneously, China's hotel market is becoming stronger and shape. To continue in the hotel industry most of hotels doing various ways to attract visitors (Padlee et al., 2019). Therefore, in recent years, with the continuous development of China's hotel industry, the competition between them is becoming fiercer. As a representative of the service industry, hotels need to seek their own living space in the fierce competition with innovative services. Service quality is the best way for hotels to gain a competitive advantage and is highly praised by customers for its distinct pertinence and flexibility. At the same time, only by providing effective service quality can the hotel establish a good reputation among customers and bring profits to the hotel. Hence, The most important and challenging task for the contemporary service industry is to provide highquality service and achieve customer satisfaction(Hung et al., 2003). Furthermore, Service Quality has become a momentous defense for hotels to stand out in the new market competition. On the other hand, Customer satisfaction studies have been paid more attention in several industries, especially in the service industry, it has become one of the important means for enterprises to find problems and improve service quality. Furthermore, The relationship between service quality and customer satisfaction is a vital research theme, given that the fierce competition in which companies(hotels) operate today, makes it very important for them to know, to what extent the satisfaction of their customers, can be a guarantor of their satisfaction. This research topic is more significant since it is recognized today that retaining a customer is cheaper than conquering a new one. As a result, several studies highlighted the relationship between service quality and customer satisfaction in the hotel industry, reporting positive and significant relationships between these two concepts (e.g., Gunarathne, 2014; Sharma and Srivastava, 2018; Ahsan, Mowla and Islam, 2019; Padlee, Thaw, and Atikah Zulkiffli, 2019) see also table 1. Therefore, the purpose of this study was to measure the relationship between service quality and customer satisfaction to identify which service quality dimensions influence customer satisfaction in the hotel industry in Changsha city.

\section{Objectives of the study}

- To investigate the relationship between Service Quality and Customer Satisfaction in the hotel industry.

- To identify the importance of service quality and customer satisfaction in the hotel industry. 


\section{LITERATURE REVIEW}

\section{A. Services Quality}

Service is the foundation of service marketing, and service quality is the core of service marketing whether it is tangible product manufacture or service industry, service quality is the magic weapon for enterprises to win in the competitions. Quality is the combination of characteristics of goods or services that promise to satisfy the express or implied needs of customers (Kotler \& Gertner, 2002). According to Mola and Jusoh ( 2011), Service quality has come out as a significant area in the hotel industry for decades. In this regard, service providers must understand customer expectations and perceptions as well as the factors that influence their evaluation and satisfaction with the services that are provided to them. Furthermore, there are many researchers who have given different interpretations of the definition of service quality from different angles. For instance, Parasuraman et al ( 1985) define service quality as the difference between the customer's expectations of the service and the customer's actual service performance, that is, the service quality is equal to the expected service minus the perceived service. While Cronin \& Taylor(1994)defined service quality as a form of attitude representing a long-run overall evaluation. Also service quality is a relativistic and cognitive discrepancy between experience-based norms and performances concerning service benefits(Roest \& Pieters, 1997).

SERVQUAL model is widely used in service industries to understand the service needs and perceptions of target customers to provide enterprises with a set of ways to manage and measure service quality. Parasuraman et al(1988) Proposed "SERVQUAL model" to measure five dimensions of service quality, namely: tangible(physical facilities, equipment, and appearance of employees), reliability (ability to perform the promised service dependably and accurately), responsiveness (willingness to help customers and provide prompt service), assurance (knowledge and courtesy of employees and their ability to inspire trust and confidence), and empathy (caring and individualized attention the firm provides its customers). This model is used by most of the researchers to identify the gap between customer expectation and their perception and fundamentally it is used to make sure better service quality (Ahsan et al., 2019). In addition to this, other studies have confirmed that "SERVQUAL instrument" is worthy of attention in the tourism industry (Candidate et al., 2011; Fick \& Brent Ritchie, 1991). From the literature review of SERVQUAL model we found that it has been used in the different service industries, e.g. hotels(Babakus \& Mangold, 1992), higher education(Boulding et al., 1993), audit firm sorted (Caruana et al., 2000), bank industry (Quyet et al., 2015), and restaurant (Dusica \& Kortoseva, 2018). due to this reason, the "SERVQUAL" approach remains the best measurement for cross-sectional research and industry benchmarking(Grönroos, 2000).

\section{B. Customer Satisfaction}

Customer Satisfaction (CS) is a kind of customer perception level, which comes from the comparison between the expected performance and customer's expectations. Like service quality, customer satisfaction has become very important(Amin et al., 2013) because it allows businesses to assess how well their product (service) and/or overall customer experience is being received by customers. According to Olever (1997) customer satisfaction is a judgment of the customer on the characteristics of the product and service or the degree to which the product and service itself meet their needs. Kant and Jaiswa ( 2017) pointed out that "Customer satisfaction is recognized unanimously as a key foundation of marketing success with a satisfied customer base playing a vital role in achieving firms' competitiveness". Barsky \& nash (2003)stated that to achieve customer satisfaction, it is an especially important strategy for hotel companies to recognize and anticipate the need of customers and be able to satisfy them. Enterprises can quickly understand and meet the needs of different customers, make greater profits than those who fail to satisfy and understand them. Indeed, without a satisfied customer, it is complex to retain a customer base and therefore to perpetuate a business. Consequently, satisfying customers is the key factor to success in the hotel business, which can be accomplished by satisfying them throughout their first visit to develop customer loyalty and build up the desire to revisit the hotel (Poon \& Low, 2005).

Several researchers have studied customer satisfaction in the hotel industry, regarding attributes that customers seek in a hotel that is important to their satisfaction in a hotel stay. Based on (J. D. Barsky \& Labagh, 1992) study, it has been found that the most important attributes a customer seeks are employee attitudes, the location of the hotel, comfort of the room, price, facilities, reception, service parking, and food and beverage. Likewise, Poon and Low ( 2005) indicated that customer satisfaction depends on hospitality, accommodation, food and beverage quality, hotel supplementary services, recreation and entertainment, security and safety, innovation and value-added services, transportation, location, appearance, price, and payment. A recent study by Jang et al. ( 2018) Identified 30 important hotel attributes via the perspective of consumers and found that staff is the most important attribute with a positive effect on user satisfaction at all times and the other attributes show consistent positive /negative effects with a minor change of their essential interpreting customer satisfaction.

\section{RESEARCH HYPOTHESIS DEVELOPMENT}

\section{A. Tangibles and Customer Satisfaction}

Tangibles indicate the appearance of physical factors such as equipment, facilities used by a service company as well as to the appearance of service employees. According to Parasuraman et al( 1988) tangibles refers to physical facilities, equipment, and appearance of personnel. Furthermore, Aspects in the tangibles factor are for instance has up-to-date equipment, physical facilities are visually appealing and materials are visually appealing. However, Gunarathne ( 2014) studied the relationship between service quality and customer satisfaction in Sri Lankan Hotel Industry. $\mathrm{He}$ found a positive relationship between tangibles and customer satisfaction. Minh et al(2015) examined the relationship between service quality and customer satisfaction in Vietnamese hotels. According to their results, tangible has no significant impact on customer satisfaction although it also has a positive correlation with customer satisfaction. Furthermore, in the research on customers' perceptions of service quality in the hotels of Himachal Pardesh 
and Haryana states by Gupta ( 2017), the result indicated that tangibility is the best predictor with the largest $\beta$ value. Based on the above discussion the first hypothesis is as follows:

H1. There is a positive relationship between tangibles and customer satisfaction.

\section{B. Reliability and Customer Satisfaction}

The reliability service quality dimension describes the capabilities of the company to fulfill promised services dependably and accurately( Parasuraman et al., 1988), within the given set requirements between the company and the customer and without making any errors. In the hotel industry, reliability means the ability of the hotel to perform service precisely and on time right at the first time. Hence, it is regarded as the most important determinant of perceptions of service quality. Gunarathne ( 2014) examined the relationship between Service Quality Dimensions and Customer Satisfaction. His results led to the acceptance of the hypothesis that there is a positive relationship between Reliability and Customer Satisfaction by positive value $(+0.116)$. The aim of Ahmad et al( 2019) study was to delve into customer satisfaction and service quality by using a modified SERVQUAL model within small- and mediumsized hotels. Their results revealed that reliability has no significant impact on visitors' satisfaction. Similarly, Ali et al ( 2021) found out that the reliability factor had a negative impact on guests satisfaction. Therefore the second hypothesis is postulated:

$\mathrm{H} 2$. There is a positive relationship between reliability and customer satisfaction.

\section{Responsiveness and Customer Satisfaction}

Responsiveness refers to the willingness to help customers and offer prompt service(Valarie A et al., 2017). It is especially diffuse where customers have complaints, requests, questions, issues, and problems. According to Gunarathne( 2014), there is a positive relationship between responsiveness and customer satisfaction by positive value (+0.440). Similarly, Omar Ali et al( 2021), indicated that responsiveness has a positive relationship with customer satisfaction. Minh et al.(2015) found that responsiveness positively significant influence on customer satisfaction. Moreover, responsiveness has a highly significant impact on customer satisfaction in the hotel industry of Ethiopia(Abebe Tessera et al., 2016). Based on the above discussion the third hypothesis can be stated as follows:

H3.There is a positive relationship between responsiveness and customer satisfaction.

\section{Assurance and Customer Satisfaction}

Valarie et al( 2017) defined Assurance as "employees' knowledge ,courtesy and the ability of the firm and its employees to inspire customer trust and confidence". It is significant for the hotel to demonstrate that it's trustworthy and merit the money, the customer is paying. The consumer should feel safe when he/she consumes different services from a hotel and would like to feel secure throughout his/her stay(Ali et al., 2021). Various studies suggest there is a positive relationship between Assurance and customer satisfaction(Ahmad et al., 2019; Ali et al., 2021; W.H.D.P, 2014). Additionally, Minh et al (2015) found that assurance significantly impact on customer satisfaction in the hotel industry. Accordingly, we posit the fourth hypothesis:

H4.There is a positive relationship between assurance and customer satisfaction.

\section{E. Empathy and Customer Satisfaction}

Parasuraman et al ( 1988) defined empathy as "the caring and individual attention the firm provides its customers". It includes access, communication, and understanding customer needs and interests. According to Valarie A et al, ( 2017), The essence of empathy is conveying, through personalized service, that customers are unique and special and that their needs are understood. From this perspective, hotel employees should be aware of the customers' requirements and preferences. In a study conducted by Ali et al(2021), on the impact of service quality on customer's satisfaction in Hotels in Erbil city in the Kurdistan region. They found that empathy has a positive relationship with customer satisfaction. Minh et al( 2015), empirically examine the relationship between service quality and customer satisfaction in Vietnamese hotels, data were collected from 432 guests of 33 three-star hotels in 2013.They indicated that empathy significantly impacts customer satisfaction. YILMAZ( 2009), in his study aims to measured hotels' service quality performance from the customer perspective in in three-star, four-star, and fivestar hotels in Nevşehir, Turkey. The author concluded that the empathy is the most important dimension in predicting hotel customers' overall service quality evaluation. Based on the preceding discussion, we proposed the fifth hypothesis:

H5. There is a positive relationship between empathy and customer satisfaction.

\section{CONCEPTUAL FRAMEWORK OF THE STUDY}

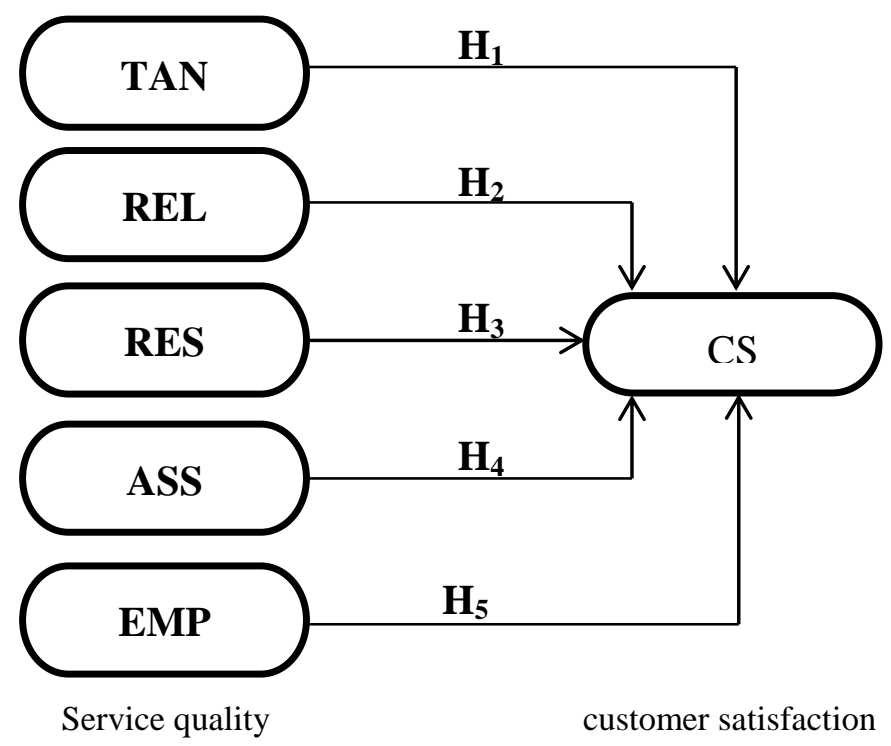

Figure 1 the theoretical model of the study

TAN: Tangible; REL: Reliability; RES: Responsiveness; ASS: Assurance; EMP: Empathy CS: customer satisfaction. 
Table 1 Summary of previous studies on service quality and customer satisfaction in hotel industry (2014-2021)

\begin{tabular}{|c|c|c|c|c|}
\hline Researchers & Year & Study & $\begin{array}{l}\text { Hotel type and } \\
\text { country }\end{array}$ & findings \\
\hline $\begin{array}{l}\text { Umesh } \\
\text { Gunarathne }\end{array}$ & 2014 & $\begin{array}{l}\text { Relationship between Service } \\
\text { Quality and Customer } \\
\text { Satisfaction in Sri Lankan } \\
\text { Hotel Industry. }\end{array}$ & Sri Lankan Hotel & $\begin{array}{l}\text { The findings of this study indicated that the } \\
\text { most important factor in predicting tourism } \\
\text { service quality evaluation was tangibility, } \\
\text { followed by empathy, reliability, and } \\
\text { responsiveness while assurance has a negative } \\
\text { relationship with customer satisfaction. }\end{array}$ \\
\hline Minh et al. & 2015 & $\begin{array}{l}\text { Service Quality and } \\
\text { Customer Satisfaction: A } \\
\text { Case Study of Hotel Industry } \\
\text { in Vietnam. }\end{array}$ & $\begin{array}{l}\text { Three-star hotels in } \\
\text { Da Nang city, } \\
\text { Vietnam }\end{array}$ & $\begin{array}{l}\text { The research results demonstrated that } \\
\text { Reliability, Responsiveness, Assurance, and } \\
\text { Empathy significantly impact on the customer } \\
\text { satisfaction while Tangible represent a non- } \\
\text { significant impact on the customer satisfaction. }\end{array}$ \\
\hline $\begin{array}{l}\text { AbebeTessera et } \\
\text { al. }\end{array}$ & 2016 & $\begin{array}{l}\text { Service Quality and Hotel's } \\
\text { Customer Satisfaction: An } \\
\text { Empirical Evidence from } \\
\text { Ethiopia. }\end{array}$ & $\begin{array}{l}\text { Various hotels from } \\
\text { Ethiopia }\end{array}$ & $\begin{array}{l}\text { Findings revealed that tangibles, } \\
\text { responsiveness, and empathy had a high } \\
\text { significant impact on customer satisfaction in } \\
\text { the hotel industry of Ethiopia. }\end{array}$ \\
\hline Deepak & 2017 & $\begin{array}{llr}\text { Service } & \text { Quality } & \text { and } \\
\text { Customer Satisfaction } & \text { in } \\
\text { Hotel Industry } & \end{array}$ & $\begin{array}{lr}\text { Five-star } & \text { hotels in } \\
\text { the } & \text { Himachal } \\
\text { Pardesh } & \text { and } \\
\text { Haryana } & \text { states, } \\
\text { India. } & \end{array}$ & $\begin{array}{l}\text { The study showed that five factors of service } \\
\text { quality play a vital role in influencing the } \\
\text { perception of customer's satisfaction }\end{array}$ \\
\hline Noor \& Ali & 2018 & $\begin{array}{l}\text { Impact of service quality on } \\
\text { customer satisfaction in hotel } \\
\text { industry of Pakistan. }\end{array}$ & $\begin{array}{l}\text { Hotels in Lahore } \\
\text { city, Pakistan. }\end{array}$ & $\begin{array}{l}\text { The authors found that there is significant and } \\
\text { positive relation among tangibility, assurance, } \\
\text { reliability, responsiveness and empathy, and } \\
\text { customer satisfaction. }\end{array}$ \\
\hline Ahmad et al. & 2019 & $\begin{array}{l}\text { Measuring service quality } \\
\text { and customer satisfaction of } \\
\text { the small- and medium-sized } \\
\text { hotels (SMSHs) industry: } \\
\text { lessons from United Arab } \\
\text { Emirates (UAE). }\end{array}$ & $\begin{array}{l}\text { SMSHs of one-to- } \\
\text { three-star ratings in } \\
\text { the UAE. }\end{array}$ & $\begin{array}{l}\text { The results indicated that dimensions of } \\
\text { SERVQUAL, namely; tangible, } \\
\text { responsiveness, and assurance, have a } \\
\text { significant positive impact on visitors' } \\
\text { satisfaction of the SMSHs Industry. The two } \\
\text { dimensions of SERVQUAL, reliability, and } \\
\text { empathy, have no significant impact on } \\
\text { visitors' satisfaction. }\end{array}$ \\
\hline Mena et al. & 2020 & $\begin{array}{l}\text { Service Quality and It's } \\
\text { Effect on Customer } \\
\text { Satisfaction in Star-Mark } \\
\text { Hotels of Shashemene Town, } \\
\text { Ethiopia. }\end{array}$ & $\begin{array}{l}\text { Hotels of } \\
\text { Shashemene Town, } \\
\text { Ethiopia }\end{array}$ & $\begin{array}{l}\text { The study revealed that Service quality } \\
\text { measurements such as reliability, } \\
\text { responsiveness, and tangibility had a significant } \\
\text { effect on customer satisfaction in star-rated } \\
\text { hotels of Shashemene town. }\end{array}$ \\
\hline Ali et al. & 2021 & $\begin{array}{l}\text { Hotel Service Quality: The } \\
\text { Impact of Service Quality on } \\
\text { Customer Satisfaction in } \\
\text { Hospitality. }\end{array}$ & $\begin{array}{l}\text { Hotels in Erbil city } \\
\text { in Kurdistan region. }\end{array}$ & $\begin{array}{l}\text { The study proved that four of service quality } \\
\text { dimensions (empathy, responsiveness, } \\
\text { assurance and tangible) have positive relation } \\
\text { with customer satisfaction, except reliability } \\
\text { had negative relation with customer } \\
\text { satisfaction. }\end{array}$ \\
\hline
\end{tabular}




\section{RESEARCH METHODOLOGY}

\section{A. Research Design}

The purpose of this study was to measure the relationship between service quality dimensions and customer satisfaction in the hotel industry in Changsha city, China. In order to do this, a Quantitative study and Descriptive research design have been adopted to make this study. Self-administered questionnaires were distributed to 6 hotels in request to be filled out by hotel guests to collect and gathered data for the study.

\section{B. Data Collection}

The study utilized both primary and secondary sources of data. A Self-administered questionnaire about service quality and customer satisfaction was used in this research to collect and gathered data by used the convenience sampling method as the primary data. On the other hand, Secondary sources were collected from articles, books, journals, publications, and other relevant Sources. The questionnaire was translated from English to the Chinese language in order to be fully understood. Data were collected from Chinese, who has stayed in Changsha hotels for business affairs, travel, visiting relatives and friends and other reason. A total of 200 questionnaires were distributed in this study 33 were invalid and 167 questionnaires were properly completed. This gave the research a response rate of $83.5 \%$ of the overall sample chosen which is a statistically acceptable.

\section{Measurement Model}

The present study employed the SERVQUAL Model which was developed by Parasuraman et al (1988) to measure service quality provided to customers. A modified SERVQUAL questionnaire relevant to the hotel industry has been constructed. Using the five service quality dimensions (tangibles, reliability, responsiveness, assurance, and empathy) with 22 measurements items for the independent variables. Customer satisfaction is the dependent variable in this research six measurements items that are relevant to measure customer satisfaction were taken from the study of Umesh Gunarathne ( 2014). Five-point Likert scale were used for all the variables with $(1=$ strongly disagree, $2=$ disagree, $3=$ neutral, $4=$ agree, $5=$ strongly agree).

\section{DATA ANALYSIS AND RESULTS}

\section{A. demographic characteristics}

From table 2, it is observed that demographics features of respondents were categorized according to their gender, age, marital status, education level, and Purpose of visit. Based on the table, it is shown that among the respondents $70.1 \%$ are male and $29.9 \%$ are female. The majority of the respondent's age is below 20 , and their ratio is $56.9 \%$, followed by age category between 21 and 30 years accounted for $20.4 \%$, then the age category from $31-40$ years old with a percentage of $18.6 \%$. $3.6 \%$ of respondent's age is 33-42, and the minority of participants is 51 years/above with only $.6 \%$. It is also shown that from the table the most of the participants are single, representing $77.2 \%$ of the total while the number of married participants with $22.8 \%$. Secondary /high school holders dominated the sample with 55.1 $\%(=167), 16$ out of 167 are a junior college with $9.6 \%$, while undergraduate respondents representing $13.8 \%$ and 36 out of 167 holding a university degree and above with 21.6 percent. The respondents reported a variety of purposes for visit the hotels, $5.4 \%$ were on business affairs followed by $13.2 \%$ on travel and $4.8 \%$ for visiting relatives /friends while the majority of the respondents visit the hotel for other purposes (transit, study, sports, health, etc.) with 76.6 percent.

Table 2 Respondents' Profile, Sample size (n) $=167$

\begin{tabular}{|c|c|c|c|}
\hline Particulars & Categories & Frequency & $\%$ \\
\hline Gender & Male & 117 & 70.1 \\
& Female & 50 & 29.9 \\
\hline Age group & Below 20 years & 95 & 56.9 \\
& $21-30$ years & 34 & 20.4 \\
& $31-40$ years & 31 & 18.6 \\
& 41-50 years & 6 & 3.6 \\
& 51years/above & 1 & 0.6 \\
\hline Marital & Single & 129 & 77.2 \\
Status & Married & 38 & 22.8 \\
\hline Education & secondary /high school & 92 & 55.1 \\
Level & Junior college & 16 & 9.6 \\
& Undergraduate & 23 & 13.8 \\
& Graduate /above & 36 & 21.6 \\
\hline Purpose of & Business affairs & 9 & 5.4 \\
visit & Travel & 22 & 13.2 \\
& Visiting relatives /friends & 8 & 4.8 \\
& Other (transit, study, etc.) & 128 & 76.6 \\
\hline
\end{tabular}

For the objective of analyzing the data collected from the respondents, Statistical Package for Social Sciences (SPSS) version 25 and Smart PLS 3 were used. To verify the validity and reliability of the scale used to measure customer satisfaction and Service Quality. KMO test and Bartlett sphere test are often used to examine the appropriateness of data for factor analysis performance. Therefore, before proceeding with the factor analysis, KMO test and Bartlett sphere test was used on the data to check the adequacy of data for conducting the factor analysis. From table 3 below, it is seen that KMO measurement value for the 28 -item questionnaire is 0.915 which is more than 0.5 . This indicates that data is very suitable and adequate for conducting factor analysis. And also Bartlett value is meaningful at 0.000 which is less than 0.05 indicating that the statistical data is relevant and adequate for proceeding analysis utilized the factor analysis.

Table 3 KMO and Bartlett's Test

\begin{tabular}{|c|c|c|}
\hline \multicolumn{2}{|c|}{$\begin{array}{l}\text { Kaiser-Meyer-Olkin Measure of Sampling } \\
\text { Adequacy }\end{array}$} & 0.915 \\
\hline $\begin{array}{l}\text { Bartlett's Test of } \\
\text { Sphericity }\end{array}$ & $\begin{array}{l}\text { Approx. Chi-Square } \\
\text { df } \\
\text { Sig. }\end{array}$ & $\begin{array}{c}2753.0 \\
60 \\
378 \\
0.000\end{array}$ \\
\hline
\end{tabular}

\section{B. Reliability and Validity Analyses}

To model the causal relationships between the five SERVQUAL constructs and the customers' satisfaction construct, we applied 
structural equation modeling analysis using SMARTPLS 3. The model was tested against the obtained measurement data to determine suitability. All scales' items that were used had factor loadings that exceeded 0.5 and were statistically significant $(\mathrm{p}<$ $0.05)$, see table 4 . To test the reliability of the constructs, the study used internal consistency was assessed via Cronbach's Alpha Coefficient and composite reliability (CR). The CRs for all the variables were higher than the recommended value of 0.7 Hair et al ( 2011). Cronbach's Alpha of each construct exceeded the threshold 0.7 Hair et al ( 2010). Therefore, the scales used were considered reliable and could be used for further analysis. The Average Variance Extracted(AVE) value of 0.50 and higher indicates a sufficient degree of convergent validity Hair et al ( 2011). Therefore, Convergent validity was acceptable due to the Average Variance Extracted (AVE) of all constructs was higher than 0.5 . The results for the reliability and validity along with the factor loadings for the items are represented in Table 4. Discriminant validity was assessed by Fornell \& Larcker criterion, Discriminant validity of the dimensions was tested by comparing AVE values to squared correlations between the constructs. the square root of AVE should be higher than its correlation with any other latent variable Fornell and Larcker (1981). The table 5 shows that the square root of the AVE values for the construct was larger than the inter-construct correlation coefficients, supporting the discriminant validity of the measures. Discriminant validity was also assessed by Heterotrait and monotrit ratio of correlations(Henseler et al., 2015). Which values below the threshold of 0.90 . Hence, discriminant validity is established see table 6 . In summary, the results indicate satisfactory reliability and convergent validity.

Table 4 Reliability and Validity for constructs

\begin{tabular}{|c|c|c|c|c|c|c|}
\hline Constructs & items & $\begin{array}{c}\text { Factor } \\
\text { loadings }\end{array}$ & Alpha & CR & AVE & Sig \\
\hline Tangibility & $\begin{array}{l}\text { 1. The hotel has visually appealing buildings and physical } \\
\text { facilities. } \\
\text { 2. The hotel has modern-looking equipment. } \\
\text { 3. The atmosphere is comfortable and appropriate for purpose } \\
\text { of stay. } \\
\text { 4. Appliances in a hotel room are maintained well. } \\
\text { 5. The hotel facilities function properly. }\end{array}$ & $\begin{array}{l}0.723 \\
0.859 \\
0.788 \\
0.755 \\
0.657\end{array}$ & 0.815 & 0.871 & 0.577 & $\begin{array}{l}0.000 \\
0.000 \\
0.000 \\
0.000 \\
0.000\end{array}$ \\
\hline Reliability & $\begin{array}{l}\text { 6. The hotel provides the services as they were promised. } \\
\text { 7. The hotel provides flexibility in services according to guest } \\
\text { demands. } \\
\text { 8. The hotel performs the services right the first time. } \\
\text { 9. The hotel employees are skillful in performing their tasks. } \\
\text { 10. The hotel is able to solve problem and cooperate. }\end{array}$ & $\begin{array}{l}0.733 \\
0.779 \\
0.680 \\
0.824 \\
0.750\end{array}$ & 0.812 & 0.868 & 0.570 & $\begin{array}{l}0.000 \\
0.000 \\
0.000 \\
0.000 \\
0.000\end{array}$ \\
\hline Responsiveness & $\begin{array}{l}\text { 11. Employees provide efficient and prompt service. } \\
\text { 12. Employees made me feel like an important person. } \\
\text { 13. Employees are always available when needed. } \\
\text { 14. Employees always treat guests in a friendly manner. }\end{array}$ & $\begin{array}{l}0.795 \\
0.756 \\
0.801 \\
0.741 \\
\end{array}$ & 0.777 & 0.856 & 0.598 & $\begin{array}{l}0.000 \\
0.000 \\
0.000 \\
0.000\end{array}$ \\
\hline Assurance & $\begin{array}{l}\text { 15. Employees instill confidence in guests. } \\
\text { 16. The hotel provides its guests a safe and secure place. } \\
\text { 17. Employees are polite, professional and friendly. } \\
\text { 18. Employees have in-depth occupational knowledge. }\end{array}$ & $\begin{array}{l}0.764 \\
0.818 \\
0.808 \\
0.800\end{array}$ & 0.809 & 0.875 & 0.636 & $\begin{array}{l}0.000 \\
0.000 \\
0.000 \\
0.000\end{array}$ \\
\hline Empathy & $\begin{array}{l}\text { 19. Employees give guest individualized attention to makes } \\
\text { them feel special. } \\
\text { 20. Employees of the hotel understand the specific needs of the } \\
\text { guests. } \\
\text { 21. Service time provided by the hotel is convenience to the } \\
\text { guests. } \\
\text { 22. Employees having flexible rules with guests. }\end{array}$ & $\begin{array}{l}0.843 \\
0.874 \\
0.833 \\
0.811\end{array}$ & 0.862 & 0.906 & 0.707 & $\begin{array}{l}0.000 \\
0.000 \\
0.000 \\
0.000\end{array}$ \\
\hline $\begin{array}{c}\text { Customer } \\
\text { Satisfaction }\end{array}$ & $\begin{array}{l}\text { 1. I intend to continue using this hotel. } \\
\text { 2. I would recommend this hotel to other people. } \\
\text { 3. I would like to stay in this hotel next time. } \\
\text { 4. I would like to repurchase many services in this hotel. } \\
\text { 5. I would encourage friends and relatives to visit this hotel. } \\
\text { 6. I consider the performance in this hotel strong. }\end{array}$ & $\begin{array}{l}0.768 \\
0.799 \\
0.804 \\
0.752 \\
0.843 \\
0.827\end{array}$ & 0.887 & 0.914 & 0.639 & $\begin{array}{l}0.000 \\
0.000 \\
0.000 \\
0.000 \\
0.000 \\
0.000\end{array}$ \\
\hline
\end{tabular}


Table 5 Discriminant validity

\begin{tabular}{|c|c|c|c|c|c|c|}
\hline & TAN & REL & RES & ASS & EMP & CS \\
\hline TAN & $\mathbf{0 . 7 6}$ & & & & & \\
\hline REL & 0.61 & $\mathbf{0 . 7 5}$ & & & & \\
\hline RES & 0.56 & 0.67 & $\mathbf{0 . 7 7}$ & & & \\
\hline ASS & 0.56 & 0.63 & 0.63 & $\mathbf{0 . 8 4}$ & & \\
\hline EMP & 0.63 & 0.62 & 0.7 & 0.68 & $\mathbf{0 . 8}$ & \\
\hline CS & 0.47 & 0.52 & 0.57 & 0.65 & 0.6 & $\mathbf{0 . 8}$ \\
\hline
\end{tabular}

Note: Bold values represent Square-root of AVE

Table 6 Heterotrait-monotrait(HTMT) Ration in the measurement model

\begin{tabular}{|c|r|r|r|r|r|l|}
\hline & \multicolumn{1}{|c|}{ TAN } & \multicolumn{1}{c|}{ REL } & RES & ASS & EMP & CS \\
\hline TAN & & & & & & \\
\hline REL & 0.75 & & & & & \\
\hline RES & 0.71 & 0.84 & & & & \\
\hline ASS & 0.67 & 0.75 & 0.77 & & & \\
\hline EMP & 0.78 & 0.75 & 0.88 & 0.81 & & \\
\hline CS & 0.55 & 0.61 & 0.68 & 0.73 & 0.7 & \\
\hline
\end{tabular}

\section{Structural model assessment}

Based on SEM-PLS, we measured the predictive power of the structural model on two main criteria: first- the coefficient of determination $\left(\mathrm{R}^{2}\right)$, which is the most common measure used to evaluate the structural model (Hair et al., 2013). As shown in Table 7 , that R-square value is 0.48 , meaning that about $48 \%$ of the endogenous latent variables (Customer satisfaction) are explained by exogenous latent variables (service quality dimensions). According to Chin ( 1998,p.323) R-square values of $0.67,0.33$, and 0.19 in SEM-PLS can be considered as substantial, moderate, and weak, respectively. Since the R2 value is moderate, scholars like (Henseler et al., 2009) accepted the moderate value of $\mathrm{R}^{2}$ to become a successful research study. Second -Standardized Root Mean Square Residual (SRMR) which is a measure of approximate fit of the researcher's model(Henseler et al., 2016). Hu and Bentler ( 1998) pointed out that a model has a good fit when SRMR is less than .08. Results presented in table 7 show that SRMR value is 0.07 meaning that the model is considered a good fit in this research. The quality criteria valuation was carried out using PLS Algorithm approach in SmartPLS3. We can conclude that both $\mathrm{R}^{2}$ and SRMR presented acceptable values. Therefore, the research structural model has an acceptable predictive quality.

Table 7 Predictive Quality Testing

\begin{tabular}{|c|l|}
\hline R Square & 0.48 \\
\hline SRMR & 0.07 \\
\hline
\end{tabular}

\section{Hypothesis Testing}

This study conducted The Structural Equation Modeling (SEM) to test the hypotheses through SMARTPLS 3.the bootstrap algorithm was employed to analyze T-statistics while The PIS algorithm was conducted to evaluate the standard path coefficients of the hypotheses. Hypotheses were tested to ascertain the relationship between service quality dimensions and customer satisfaction, the results are presented in Figure 2-3 and table8 which indicates that first, tangibility insignificantly correlated with customer satisfaction $(\beta=0.023, t=0.292, P$ $>0.05)$. Hence, $\mathrm{H} 1$ was not supported. Second, reliability also insignificantly correlated with customer satisfaction $(\beta=0.057$, $\mathrm{t}=0.57, \mathrm{P}>0.05)$ therefore $\mathrm{H} 2$ was not Supported. Third, the relationship between responsiveness significantly correlated with customer satisfaction $(\beta=0.154, \mathrm{t}=2.037, \mathrm{P}>0.05)$ showing that H3 was Supported. Fourth, Assurance is significantly associated with customer satisfaction $(\beta=0.379, \quad \mathrm{t}=4.448, \quad \mathrm{P}>0.05$ (supporting H4. Finally, the relationship between Empathy significantly correlated with customer satisfaction $(\beta=0.180$, $\mathrm{t}=2.128, \mathrm{P}>0.05)$.therefore, $\mathrm{H} 5$ was supported.

\section{DISCUSSION}

The purpose of this study has been to investigate the relationship between service quality dimensions (tangibility, reliability, responsiveness, assurance, and empathy) and customer satisfaction from the perceptions of guests in the hotel industry namely Changsha city. Previous research has applied the SERVQUAL model to measure customer satisfaction in the hotel industry(Ahmad et al., 2019; Ali et al., 2021; Umesh Gunarathne, 2014), which was developed by Parasuraman, Zeithaml, Berry ( 1988). Therefore, this study adopted SERVQUAL to measure the 
Table 8 The Summery of the hypotheses testing

\begin{tabular}{|c|l|c|c|l|l|l|}
\hline Hypo & \multicolumn{1}{|c|}{ Relationship } & $\begin{array}{c}\text { Std. } \\
\text { Beta }\end{array}$ & $\begin{array}{c}\text { Std. } \\
\text { Error }\end{array}$ & \multicolumn{1}{|c|}{ T-value } & P-value & \multicolumn{1}{|c|}{ Direction } \\
\hline H1 & Tangibility $\rightarrow$ Customer Satisfaction & 0.023 & 0.082 & 0.292 & 0.770 & Not Supported \\
\hline H2 & Reliability $\rightarrow$ Customer Satisfaction & 0.057 & 0.092 & 0.652 & 0.515 & Not Supported \\
\hline H3 & Responsiveness $\rightarrow$ Customer Satisfaction & 0.154 & 0.077 & 2.037 & $0.042^{*}$ & Supported \\
\hline H4 & Assurance $\rightarrow$ Customer Satisfaction & 0.379 & 0.084 & 4.448 & $0.000^{* *}$ & Supported \\
\hline H5 & Empathy $\rightarrow$ Customer Satisfaction & 0.180 & 0.086 & 2.128 & $0.034^{*}$ & Supported \\
\hline
\end{tabular}

Significant at $\mathrm{P} * *=<0.01, \mathrm{p}^{*}<0.05$

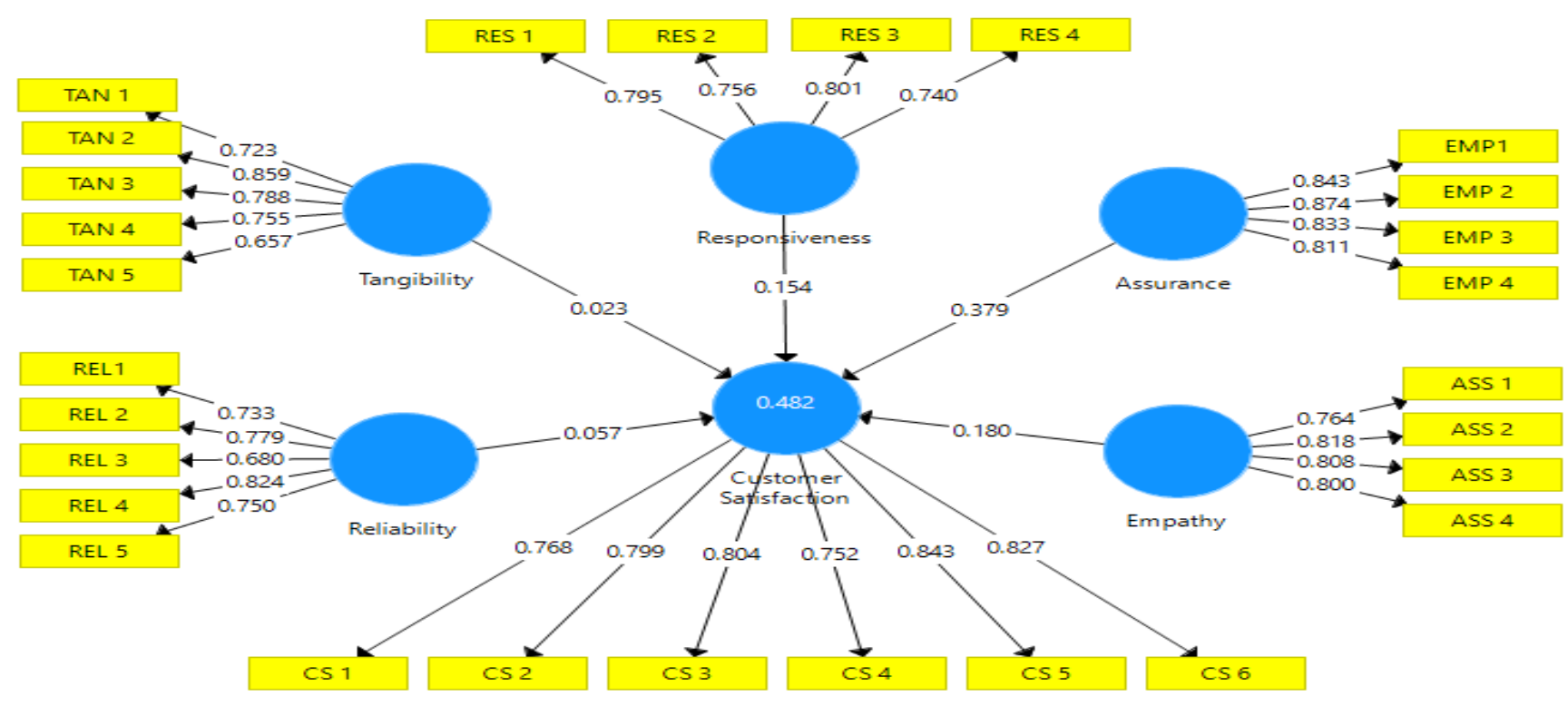

Figure 2 Standardized Path Coefficients for the hypotheses

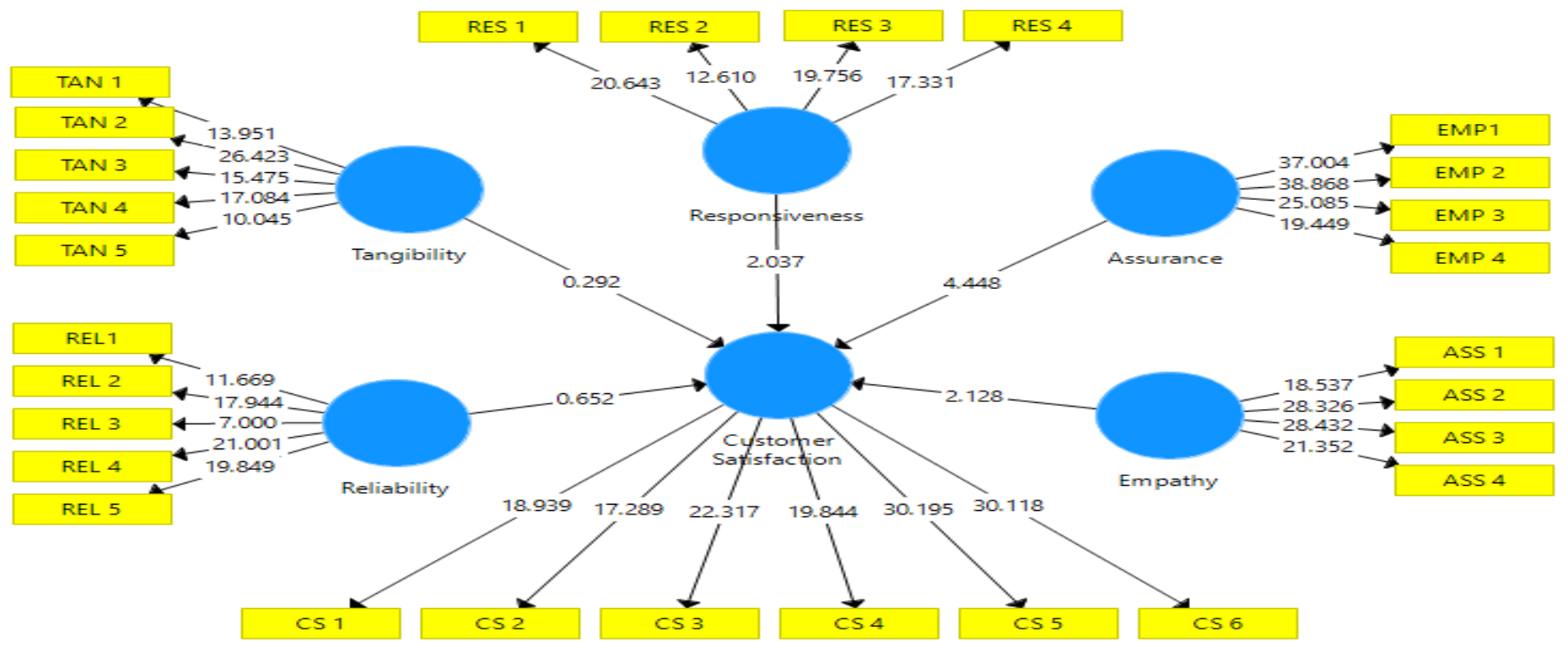

Figure 3 T-Statistics Using Bootstrap Algorithm 
relationship between service quality and customer satisfaction in the hotel industry. In order to measure the reliability and validity of instruments used in this study, composite reliability (CR), Cronbach's alpha, Discriminant validity, Heterotrait-monotrait (HTMT) respectively were used. The CRs for all the variables were higher than the recommended value of 0.7 Hair et al (2011), Cronbach's Alpha of each construct exceeded the threshold 0.7 Hair et al (2010), See table 4. the square root of the AVE values for the construct was larger than the inter-construct correlation coefficients Fornell and Larcker (1981), see table 5 . Heterotrait-monotrait (HTMT) ratio of correlations below the threshold of 0.90 ((Henseler et al., 2015), see table 6. The results of reliability and validity testing of five service quality dimensions and customer satisfaction in the research were satisfactory; therefore, they are all acceptable for analysis.

Based on a structural equation modeling analysis, the results revealed that the first hypothesis, tangibility has insignificantly correlated with customer satisfaction although it has a positive correlation with customer satisfaction $(\beta=0.023, t=0.292$, $\mathrm{P}>0.05)$. Therefore, the $\mathrm{H} 1$ was Not Supported. A reasonable explanation for this could be due to Respondent's different educational background, marital status, age, etc. But still, tangibility could be a factor that influences guests positively and significantly in the hotel industry. This result is consistent with Minh et al (2015) whose study has found that tangibility has a non-significant impact on customer satisfaction. In contrast to previous studies(Ali et al., 2021; Noor \& Ali, 2018; W.H.D.P, 2014) whose studies have found that tangibility has a positive and significant impact on customer satisfaction. The second hypothesis, reliability has not significantly predicted customer satisfaction although it has a positive correlation with customer satisfaction $(\beta=0.057, \mathrm{t}=0.57, \mathrm{P}>0.05)$ Therefore, based on this result the $\mathrm{H} 2$ was not supported. A reasonable explanation for this could be due to Respondent's different educational background, marital status, age, etc. But still, reliability could be a factor that affects guests positively and significantly in the hotel industry. This result is consistent with a previous study(Ali et al., 2021) whose study revealed that reliability has not significantly predicted customer satisfaction. In contrast to previous studies(Gupta, 2017; Mena et al., 2020; Minh et al., 2015) whose studies have indicated that reliability positively and significantly impacts customer satisfaction. The third hypothesis, responsiveness has significantly predicted customer satisfaction $(\beta=0.154, \mathrm{t}=2.037, \mathrm{P}<0.05)$ showing that responsiveness has a positive relationship with customer satisfaction. Therefore, based on this result the $\mathrm{H} 3$ was supported. This result was supported by some authors who indicate the same results in their research studies(Abebe Tessera et al., 2016; Noor \& Ali, 2018; Omar Ali et al., 2021; W.H.D.P, 2014). The fourth hypothesis, Assurance significantly associated with customer satisfaction $(\beta=0.379$, $\mathrm{t}=4.448, \mathrm{P}<0.05)$ this indicates that assurance has a positive relationship with customer satisfaction. Assurance was found to have the highest impact on customer satisfaction. Therefore, based on this result the $\mathrm{H} 4$ was supported. This consequence is in the line with previous studies(Abebe Tessera et al., 2016; Ahmad et al., 2019; Ali et al., 2021; Minh et al., 2015). In contrast to a previous study(W.H.D.P, 2014) whose indicated that there is a negative relationship between Assurance and Customer Satisfaction. Finally, the fifth hypothesis, states that there is a positive relationship between empathy and customer satisfaction, according to the data $(\beta=0.180, \mathrm{t}=2.128, \mathrm{P}<0.05)$ this indicates that empathy has a positive relationship with customer satisfaction Therefore; based on this result the H5 was supported. This result is consistent with Ali et al (2021) and W.H.D.P( 2014) whose studies have found that empathy have a positive relationship with customer satisfaction in hotel industry.

\section{CONCLUSION}

This research measured the hotel service quality to investigate customer satisfaction and describe the relationship between service quality and customer satisfaction in the hotel industry in Changsha city. The researcher found that customer satisfaction of Changsha hotels is determined by the service quality dimensions which are tangibility, reliability, responsiveness, assurance and empathy. Moreover, knowing the relationship between service quality and customer satisfaction can assist hotel managers to overcome the challenge of improving service quality in the hotel industry(Gunarathne, 2014). The findings predicted Assurance as the highest factor outcome of service quality evaluation by customers upon the six local hotels in Changsha. This was followed by Empathy and then Responsiveness. The findings also identified tangibility and reliability as two service quality dimensions that did not produce a significant influence on customer satisfaction, but they have a positive relationship with customer satisfaction. A reasonable explanation for this could be due to Respondent's different educational background, marital status, and age, etc. But still, tangibility and reliability could be factors that affect guests positively and significantly in the hotel industry.in conclusion, knowing how consumers perceive service quality and being able to measure service quality can benefit for hotel management to enhance service quality leading increasing level of customer satisfaction.in addition, the association between service quality and customer satisfaction will help hotel management to clarify what these service quality dimensions mean to the hotel guests and to the hotel itself. This enables hotel managers to gain a better understanding of how the respective service quality dimensions affect customer satisfaction. This skill can create a blue ocean for the hotel managers, which is an effective competitive advantage(Padlee et al., 2019).furthermore, this study provides hotel managers with a scale to evaluate the quality of their service from the perspective of the five 
underlying dimensions called SERQUAL. By using the SERVQUAL model in this study, the researcher attempting to measure service quality and customer satisfaction and find out it was a reliable instrument and a useful tool for assessing hotel service quality. Therefore, hotel management should enhance the employee's performance by development programs, training, and motivate them to make friendly interaction with customers, solve customer problems and provide superior service quality.

\section{LIMITATIONS AND SUGGESTIONS FOR FUTURE RESEARCH}

This study measures the relationship between service quality and customer satisfaction from the perspective of hotel customers only 6 hotels located in the Yuelu district of Changsha city. However, the results may therefore reflect specific target hotels that are not representative of the entire hotel industry of Changsha city, hence limited geographical area and data analyzed only considering 167 questionnaires. Due to the sample size of this study was very small and used the convenience sampling method to collect the data future studies in this field could address this problem by using larger and random samples.

\section{REFERENCES}

[1] Abebe Tessera, F., Alisa Hussain, I., \& Ahmad, N. (2016). Service Quality and Hotel's Customer Satisfaction: An Empirical Evidence from Ethiopia. In Electronic Journal of Business and Management (Vol. 1, Issue 1).

[2] Ahmad, S. Z., Ahmad, N., \& Papastathopoulos, A. (2019). Measuring service quality and customer satisfaction of the small- and medium-sized hotels (SMSHs) industry: lessons from United Arab Emirates (UAE). Tourism Review, 74(3), 349-370. https://doi.org/10.1108/TR-10-2017-0160

[3] Ahsan, S. H., Mowla, M. M., \& Islam, M. (2019). Investigating the Relationship between Service. 19(1).

[4] Ali, B. J., Gardi, B., Jabbar Othman, B., Ali Ahmed, S., Burhan Ismael, N., Abdalla Hamza, P., Mahmood Aziz, H., Sabir, B. Y., Sorguli, S., \& Anwar, G. (2021). Hotel Service Quality: The Impact of Service Quality on Customer Satisfaction in Hospitality. Ali, BJ, Gardi, B., Othman, BJ, Ahmed, SA, Ismael, NB, Hamza, PA, Aziz, HM, Sabir, BY, Anwar, G.(2021). Hotel Service Quality: The Impact of Service Quality on Customer Satisfaction in Hospitality. International Journal of Engineering, Business and Manage, 5(3), 14-28.

[5] Amin, M., Yahya, Z., Ismayatim, W. F. A., Nasharuddin, S. Z., \& Kassim, E. (2013). Service Quality Dimension and Customer Satisfaction: An Empirical Study in the Malaysian Hotel Industry. Services Marketing Quarterly, 34(2), 115-125. https://doi.org/10.1080/15332969.2013.770665

[6] Babakus, E., \& Mangold, W. G. (1992). Adapting the SERVQUAL scale to hospital services: an empirical investigation. Health Services Research, 26(6), 767-786.

[7] Barsky, J. D., \& Labagh, R. (1992). A Strategy for Customer Satisfaction. Cornell Hotel and Restaurant Administration Quarterly, 33(5), 32-40. https://doi.org/10.1177/001088049203300524

This publication is licensed under Creative Commons Attribution CC BY. http://dx.doi.org/10.29322/IJSRP.11.08.2021.p11644
[8] Barsky, J., \& Nash, L. (2003). Customer Satisfaction: Applying Concepts to Industry-wide Measures. Cornell Hotel and Restaurant Administration Quarterly - CORNELL HOTEL RESTAUR ADMIN $Q, 44,173-183$. https://doi.org/10.1016/S0010-8804(03)90122-4

[9] Boulding, W., Kalra, A., Staelin, R., \& Zeithaml, V. (1993). A Dynamic Process Model of Service Quality: From Expectations to Behavioral Intentions. Journal of Marketing Research, 30, 7-27. https://doi.org/10.2307/3172510

[10] Candidate, M. S., Amjad, U., \& Shaikh, A. (2011). Impact of Service Quality on Customer Satisfaction: Evidences From the Restaurant Industry in Pakistan. Management \& Marketing, IX(2), 343-355.

[11] Caruana, A., Money, A., \& Berthon, P. (2000). Service quality and satisfaction: The moderating role of value. European Journal of Marketing, 34, 1338-1353. https://doi.org/10.1108/03090560010764432

[12] Chin, W. W. (1998). The partial least squares approach to structural equation modeling. Modern Methods for Business Research, 295(2), 295-336.

[13] Cronin. Jr, J. (1994). SERVPERF Versus SERVQUAL: Reconciling Performance-Based and Perceptions-Minus-Expectations Measurement of Service Quality. Journal of Marketing, 58, 125131. https://doi.org/10.1177/002224299405800110

[14] Dusica, S., \& Kortoseva, S. (2018). Service Quality in Restaurants: Customers' Expectation and Customers' Perception. 47-52. https://doi.org/10.18421/SAR12-03

[15] Fick, G. R., \& Brent Ritchie, J. R. (1991). Measuring Service Quality in the Travel and Tourism Industry. Journal of Travel Research, 30(2), 2-9. https://doi.org/10.1177/004728759103000201

[16] Fornell, C., \& Larcker, D. F. (1981). Evaluating Structural Equation Models with Unobservable Variables and Measurement Error. Journal of Marketing Research, 18(1), 39-50. https://doi.org/10.1177/002224378101800104

[17] Grönroos, C. (2000). Service Management and Marketing: A Customer Relationship Management Approach.

[18] Gupta, D. (2017). Service Quality \& Customer Satisfaction in Hotel Industry. International Journal of Techno-Management Research, 5(2), 41-55.

[19] Hair, J. F., Hult, G. T. M., Ringle, C. M., \& Sarstedt, M. (2013). A Primer on Partial Least Squares Structural Equation Modeling (PLSSEM). Thousand Oaks. Sage, 165.

[20] Hair, J. F. J., Black, W. C., Babin, B. J., Anderson, R. E., \& Tatham, R. (2010). Multivariate data analysis upper saddle river: pearson prentice hall. Links.

[21] Hair, J. F., Ringle, C. M., \& Sarstedt, M. (2011). PLS-SEM: Indeed a silver bullet. Journal of Marketing Theory and Practice, 19(2), 139-152.

[22] Henseler, J., Hubona, G., \& Ray, P. A. (2016). Using PLS path modeling in new technology research: updated guidelines. Industrial Management \& Data Systems, 116(1), 2-20. https://doi.org/10.1108/IMDS-09-2015-0382

[23] Henseler, J., Ringle, C. M., \& Sarstedt, M. (2015). A new criterion for assessing discriminant validity in variance-based structural equation modeling. Journal of the Academy of Marketing Science, 43(1), 115-135.

[24] Henseler, J., Ringle, C. M., \& Sinkovics, R. R. (2009). The use of partial least squares path modeling in international marketing. In R. 
R. Sinkovics \& P. N. Ghauri (Eds.), New Challenges to International Marketing (Vol. 20, pp. 277-319). Emerald Group Publishing Limited. https://doi.org/10.1108/S14747979(2009)0000020014

[25] Hu, L., \& Bentler, P. M. (1998). Fit indices in covariance structure modeling: Sensitivity to underparameterized model misspecification. Psychological Methods, 3(4), 424.

[26] Hung, Y. H., Huang, M. L., \& Chen, K. S. (2003). Service quality evaluation by service quality performance matrix. Total Quality Management \& Business Excellence, 14(1), 79-89. https://doi.org/10.1080/14783360309706

[27] Jang, S., Liu, T., Kang, J. H., \& Yang, H. (2018). Understanding important hotel attributes from the consumer perspective over time. Australasian Marketing Journal (AMJ), 26(1), 23-30. https://doi.org/https://doi.org/10.1016/j.ausmj.2018.02.001

[28] Kant, R., \& Jaiswal, D. (2017). The impact of perceived service quality dimensions on customer satisfaction: An empirical study on public sector banks in India. International Journal of Bank Marketing, 35. https://doi.org/10.1108/IJBM-04-2016-0051

[29] Kotler, P., \& Gertner, D. (2002). Country as brand, product, and beyond: A place marketing and brand management perspective. Journal of Brand Management, 9(4), 249-261. https://doi.org/10.1057/palgrave.bm.2540076

[30] Mena, T. M., Zaveri, B., \& Zeberga, F. W. (2020). SERVICE QUALITY AND IT'S EFFECT ON CUSTOMER SATISFACTION IN STAR-MARK HOTELS OF SHASHEMENE TOWN, ETHIOPIA. International Journal of Management (IJM), 11(9).

[31] Minh, N. H., Ha, N. T., Anh, P. C., \& Matsui, Y. (2015). Service quality and customer satisfaction: A case study of hotel industry in Vietnam. Asian Social Science, 11(10), 73.

[32] Mola, F., \& Jusoh, J. (2011). Service Quality in Penang Hotels: A Gap Score Analysis. World Applied Sciences Journal, 12, 19-24.

[33] Noor, S., \& Ali, M. (2018). Impact of Service Quality on Customer Satisfaction in Hotel Industry of Pakistan. Singaporean Journal of Business, Economics and Management Studies, 51(6086), 1-9.

[34] Olever, R. L. (1997). Satisfaction: a behavioral perspective on the customer. New York: Irwin McGraw Hill.

[35] Omar Ali, S. R., Norizan, S. N., Mohd Said, N. S., Mat, K. A., \& Jislan, F. (2021). Assessing Customer Satisfaction Towards Service Quality in the Hospitality Industry. Jurnal Intelek, 16(1), 67-73. https://doi.org/10.24191/ji.v16i1.365

[36] Padlee, S. F., Thaw, C. Y., \& Atikah Zulkiffli, S. N. (2019). The relationship between service quality, customer satisfaction and behavioural intentions in the hospitality industry. Tourism and Hospitality Management, 25(1), 121-139. https://doi.org/10.20867/thm.25.1.9
[37] Parasuraman, A. P., Zeithaml, V., \& Berry, L. (1988). SERVQUAL A Multiple-item Scale for Measuring Consumer Perceptions of Service Quality. Journal of Retailing, 64, 12-40.

[38] Parasuraman, A., Zeithaml, V. A., \& Berry, L. L. (1985). A Conceptual Model of Service Quality and Its Implications for Future Research. Journal of Marketing, 49(4), 41. https://doi.org/10.2307/1251430

[39] Poon, W. C., \& Low, K. (2005). Are travelers satisfied with Malaysian hotels? International Journal of Contemporary Hospitality Management, 17, 217-227. https://doi.org/10.1108/09596110510591909

[40] Quyet, T., Vinh, N., \& Chang, T. (2015). Service Quality Effects on Customer Satisfaction in Banking Industry. International Journal of $U$ - and e-Service, Science and Technology, 8, 199-206. https://doi.org/10.14257/ijunesst.2015.8.8.20

[41] Roest, H., \& Pieters, R. (1997). The nomological net of perceived service quality. International Journal of Service Industry Management, $8(4), \quad 336-351$. https://doi.org/10.1108/09564239710174408

[42] Sharma, S., \& Srivastava, S. (2018). Relationship between Service Quality and Customer Satisfaction in Hotel Industry. TRJ Tourism Research Journal; Vol 2 No 1 (2018): (TRJ) Tourism Research JournalDO $\quad$ - $\quad$ 10.30647/Trj.V2i1.20 http://trj.stptrisakti.ac.id/index.php/trj/article/view/20

[43] Valarie A, Z., Mary, J. B., \& Dwayne D, G. (2017). Services Marketing: Intergrating Customer Focus Across the Firm (p. 87). McGraw Hall.

[44] W.H.D.P, U. G. (2014). Relationship between Service Quality and Customer Satisfaction in Sri Lankan Hotel Industry. International Journal of Scientific and Research Publications, 4(11), 2250-3153.

[45] YILMAZ, I. (2009). Measurement of Service Quality in the Hotel Industry. Anatolia, 20(2), 375-386. https://doi.org/10.1080/13032917.2009.10518915

\section{AUTHORS}

First Author - Mushref Saeed

Second Author - Zhang Xizheng

Third Author - Rasheed Abdulwase

Fourth Author - Mohammed A.AL-Methali 
International Journal of Scientific and Research Publications, Volume 11, Issue 8, August 2021

This publication is licensed under Creative Commons Attribution CC BY. 